\title{
ANALISIS PUTUSAN TENTANG GUGATAN WANPRESTASI TERHADAP PENGINGKARAN JANJI KAMPANYE OLEH PRESIDEN TERPILIH
}

\author{
Riana Susmayanti, Fakultas Hukum Universitas Brawijaya, Jl. MT. Haryono 169 Malang \\ E-mail : rerezain@yahoo.co.id Telp. 0341-553898
}

\begin{abstract}
In Indonesia, the denial of campaign promises has been tried to be brought into the court. In 2009, the Indonesian Voter Institution (LPI) formally filed a lawsuit against President Susilo Bambang Yudhoyono (SBY) and Vice President M. Jusuf Kalla (JK) who failed in fulfilling campaign promises in the 2004 Presidential Election. This normative juridical research with a case study towards Central Jakarta District Court Decision No. 17 / PDT.G / 2009 / PN.JKT.PST to understand the legal reasons. The court decision was right that campaign promises do not meet the legal requirements as the agreement based on Article 1320 of the Civil Code.
\end{abstract}

Keywords : campaign promise, citizen lawsuit

\section{PENDAHULUAN}

Pemilihan umum ${ }^{1}$ berperan penting sebagai proses rekrutmen politik modern ${ }^{2}$ dan ciri negara demokratis. Keterkaitan Pemilu dan demokrasi sebagaimana pendapat Rene Descartes $^{3}$ digambarkan sebagai : "aku berdemokrasi, karenanya pemilu itu ada". Bahkan untuk mengisi jabatan-jabatan politik, negara yang tidak demokratis pun turut mengadakan pemilu. ${ }^{4}$

Pemilu adalah urat nadi demokrasi, ${ }^{5}$ pemilih harus berhati-hati dalam menjatuhkan pilihan saat pemilu. Bahkan Abraham Lincoln (1856) menyatakan "The Ballot is stronger than the bullet" (surat suara lebih kuat dari peluru). ${ }^{6}$ Idealnya demokrasi melahirkan pemilu yang demokratis. Jika pemilu terselenggara secara demokratis, maka demokrasi eksis hakiki. Jika pemilu gagal, maka demokrasi mati sejati. ${ }^{7}$

Pemilu dilaksanakan dalam beberapa tahapan. Kampanye sebagai tahapan pemilu dapat berupa rapat umum atau pertemuan ${ }^{8}$. Partai politik bersaing menyampaikan

\footnotetext{
1 Selanjutnya disebut 'Pemilu'.

2 Sigit Pamungkas, Perihal Pemilu, Laboratorium Jurusan Ilmu Pemerintahan Dan Jurusan Ilmu Pemerintahan Universitas Gadjah Mada, Yogyakarta, 2009, h. vii

${ }^{3}$ Rene Descartes (filsuf Perancis, 1596-1650) menyatakan : "cogito ergo sum" artinya "I think, therefore I am, aku berpikir, karenanya aku ada". Pendapat ini digunakan untuk menggambarkan keterkaitan demokrasi dan pemilu.

${ }^{4}$ Sigit Pamungkas, Op.Cit, h. v-vi

${ }^{5}$ Denny Indrayana, Negara Antara Ada Dan Tiada : Reformasi Hukum Ketatanegaraan, Penerbit Buku Kompas, Jakarta, Juni 2008, h. 177

${ }^{6} \mathrm{Ibid}, \mathrm{h} .166$

${ }^{7} \mathrm{Ibid}$.

${ }^{8}$ Yang berisi pidato, pembicaraan, penyampaian slogan, penyebaran barang cetakan dan rekaman berisikan kalimat ajakan, bujukan, gambar, suara, atau simbol yang secara persuasif mengajak pendengar, pemirsa atau pembaca untuk menjatuhkan pilihannya pada kandidat atau partai politik tertentu. Baca : Solatun Dulah Sayuti, Komunikasi Pemasaran Politik, PT Remaja Rosdakarya, Bandung, 2014, h. 108
} 
program unggulan 5 (lima) tahunan ${ }^{9}$ untuk meyakinkan pemilih. Pemilu merupakan bentuk minimal partisipasi politik. Tanpa partisipasi politik, demokrasi terancam lumpuh. ${ }^{10}$ Namun Pemilu seharusnya tidak dimaknai sebagai pesta demokrasi. Jika Pemilu dianggap adalah pesta demokrasi, maka pesta demokrasi otomatis berakhir saat pemilu usai. Oleh karena itu, sejatinya pesta demokrasi adalah implementasi janji kampanye dari pemenang pemilu dalam melaksanakan pemerintahan dari, oleh dan untuk rakyat.11

Sayangnya implementasi janji kampanye dari kandidat yang telah memenangkan pemilu, diibaratkan 'jauh panggang daripada api'. Agenda politik yang sarat kepentingan, membuat pemerintah mendadak lupa akan janji-janji yang diucapkan saat pemilu. Janji kampanye tersebut hanya indah diucapkan, namun selalu sulit dilaksanakan. Penggunaan bahasa dalam berpolitik, bersifat sewenang-wenang, ganda, majemuk. Tidak ada satu kata pun yang mempunyai makna tunggal, sehingga bahasa tidak bersifat netral atau obyektif. ${ }^{12}$

Mengobral janji berlebihan dalam kampanye di luar kemampuan dapat mencirikan gangguan bipolar, dimana seseorang memasuki keadaan 'manik' (sangat antusias). ${ }^{13}$ Menurut Syamsul Hadi, Guru Besar Bidang Psikiatri Universitas Negeri Sebelas Maret (UNS) Solo, gangguan bipolar merupakan gangguan yang terjadi pada otak yang menyebabkan perubahan suasana hati secara ekstrim. Gangguan ini tidak dapat mutlak dideteksi, namun dapat dilihat dari perkataan yang berlebihan di luar batas kemampuan yang dimiliki. Di sisi lain, gangguan ini menyebabkan mudah depresi, kinerja buruk, bahkan mudah mendorong keinginan untuk bunuh diri saat gagal memperoleh sesuatu. ${ }^{14}$ Ini yang menyebabkan fenomena 'Caleg Depresi Pasca Pemilu'15 menjadi logis dan realistis.

Salah satu perbedaan pemilu legislatif ${ }^{16}$ dan pemilu Presiden ${ }^{17}$ adalah jumlah kandidat. Pasangan calon Presiden dan Wakil Presiden ${ }^{18}$ lebih dikenal oleh masyarakat, karena jumlahnya lebih sedikit dibandingkan dengan calon legislatif ${ }^{19}$. Pada Pilpres, rakyat akan memilih kandidat yang dipercaya dapat memenuhi janji kampanyenya. Jika

\footnotetext{
9 Rully Ferdian, Janji Muluk Parpol Di Masa Kampanye (Online), http://www.infobanknews.com/2014/03/janji-muluk-parpol-di-masa-kampanye/nasional (Diakses 25 April 2014)

${ }^{10}$ Paulinus Yan Olla, Rakyat Dan Kepemimpinan, Kompas, 19 Oktober 2013

11 Ibnu Tri Cahyo Dalam Riana Susmayanti, Materi Kuliah Hukum Pemerintahan Daerah, Fakultas Hukum Universitas Brawijaya, Malang, 2012.

${ }_{12}$ Deddy Mulyana, Komunikasi Politik, Politik Komunikasi : Membedah Visi Dan Gaya Komunikasi Praktisi Politik, PT Remaja Rosdakarya, Bandung, 2013, h. 19.

13 Wibowo, Mataharinews.Com, Yogyakarta, 26 Maret 2014, Obral Janji Dalam Kampanye Indikasi Bipolar (Online), http:// www.mataharinews.com/nusantara/jawa-bali/3753-obral-janjidalam-kampanye-indikasi-bipolar.pdf (Diakses 17 Mei 2014)

$14 \mathrm{Ibid}$.

15 Kony Fahran, Februari 2014, Pasca Pemilu Caleg Depresi Berat Diprediksi Naik 20 Persen (Online), Jakarta, http:// beritakaltara.com/?p=2777 (Diakses 17 Mei 2014)

${ }^{16}$ Pemilu legislatif juga sering disebut dengan 'Pileg'.

17 Pemilu Presiden selanjutnya disebut 'Pilpres'.

18 Selanjutnya disebut 'capres dan cawapres'.

19 Selanjutnya disebut 'caleg'.
} 
kandidat tersebut memenangkan Pilpres, maka rakyat akan menagih janji kampanye yang pernah disampaikan.

Terkait proses kandidat menawarkan janji kampanye sehingga rakyat memilihnya, merupakan konsekuensi dari demokrasi. Namun Aristoteles menolak demokrasi sebagai sistem politik bernegara. Menurutnya, demokrasi itu menyesatkan karena menyerahkan haluan negara kepada rakyat biasa. Sedangkan pilihan rakyat tergantung pada siapa yang membayar ${ }^{20}$. Demokrasi disusupi demagog, atau agitator yang menipu rakyat dengan janji palsu. Namun setelah terpilih, mereka mengkhianatinya. ${ }^{21}$

Di Indonesia, pengingkaran janji kampanye Presiden Susilo Bambang Yudhoyono $(\mathrm{SBY})^{22}$ dan Wapres M. Jusuf Kalla (JK) ${ }^{23}$ pada Pilpres 2004 telah digugat oleh Boni Hargens dari Lembaga Pemilih Indonesia (LPI) dan 71 orang lainnya. ${ }^{24}$ Selain menagih janji kampanye, gugatan tersebut ditujukan bagi pendidikan politik rakyat, agar bersikap kritis terhadap pemimpinnya. ${ }^{25}$ Menurut penulis, terbukanya akses rakyat untuk meminta pertanggungjawaban janji kampanye, justru mewujudkan Teori Kedaulatan Rakyat secara nyata.

Dari Putusan PN Jakarta Pusat No. 17/PDT.G/2009/PN.JKT.PST tersebut terdapat beberapa isu hukum : 1) Bagaimana konstruksi hukum perbuatan pengingkaran janji kampanye oleh pemerintah ? dan 2) Bagaimana dasar pertimbangan hukum putusan tentang gugatan citizen lawsuit terhadap perbuatan wanprestasi oleh pemerintah?

\section{METODE PENELITIAN}

Penelitian yuridis normatif ini menggunakan studi kasus (case study)26 untuk menganalisis bahan hukum primer yaitu Putusan PN Jakarta Pusat No. 17/PDT.G/2009/PN.JKT.PST dan memahami alasan-alasan hukum hakim dalam putusannya ${ }^{27}$. Keterkaitan perkara dan peraturan perundang lainnya didapat dengan penelusuran kepustakaan (library research) di pusat dokumentasi dan informasi hukum, perpustakaan pada instansi terkait, bahkan internet.

\footnotetext{
${ }^{20}$ Pilihan rakyat dapat bersifat buta, tiba-tiba atau transaksional

${ }^{21}$ Moh. Mahfud MD, Konstitusi Dan Hukum Dalam Kontroversi Isu, Rajawali Pers, Jakarta, 2010, h. 410

${ }^{22}$ Sebagai Tergugat I.

${ }^{23}$ Sebagai Tergugat II.

24 Pada 23 Januari 2009, gugatan tersebut diserahkan oleh Panca N, kuasa hukum LPI, ke bagian pengajuan gugatan perdata Pengadilan Negeri (PN) Jakarta Pusat. Gugatan tersebut diterima oleh Panitia Muda Perdata (Panmud Perdata) Ibnu Sutama yang mencatat gugatan tersebut dalam register Nomor 17/PDT.G/2009/PN.JKT.PST. Baca : LPI Resmi Gugat SBY-JK, http:// partaigerindra.or.id/2009/01/23/lpi-resmi-gugat-sby-jk.html (8 Juli 15).

25 Ruslan Burhani, Kamis, 19 Februari 2009, PN Jakpus Tunda Sidang Gugatan LPI Terhadap SBY-JK, http://www.antaranews.com/berita/133289/pn-jakpus-tunda-sidang-gugatan-lpiterhadap-sby-jk.

26 Meskipun case approach dan case study (studi kasus) merupakan pendekatan penelitian berbasis kasus, namun keduanya memiliki perbedaan signifikan. Case approach menganalisis beberapa kasus sebagai referensi, sedangkan study case menganalisis kasus tertentu dari berbagai aspek hukum.

27 Peter Mahmud Marzuki, Penelitian Hukum, (Jakarta: Kencana, 2011), h. 119.
} 


\section{PEMBAHASAN}

\subsection{Konstruksi Hukum Dari Tindakan Pengingkaran Janji Kampanye Oleh Pemerintah}

Kata "pengingkaran" berasal dari kata "ingkar". Pada Kamus Besar Bahasa Indonesia, "ingkar" termasuk kata kerja yang mempunyai arti : “1 menyangkal; tidak membenarkan; tidak mengaku; mungkir: berarti akankeesaan Tuhan; 2 tidak menepati; 3 tidak mau; tidak menurut: ia pun $\sim$ dan tiada lagi mempedulikan keaiban". Sedangkan "pengingkaran" termasuk kata benda yang berarti : "perbuatan (hal, cara, dan sebagainya) mengingkari: biasanya dinyatakan dengan kata "tidak" atau "bukan"; keingkaran hal ingkar (menyangkal, tidak menurut, tidak mengaku, dan sebagainya)".

Selanjutnya Kamus Hukum mendefinisikan : “Janji adalah a) perkataan yang menyatakan kesediaan dan kesanggupan untuk berbuat atau melakukan/melaksanakan sesuatu seperti hendak memberi, menolong, datang, bertemu dan sebagainya; b) persetujuan antara dua pihak dimana masing-masing menyatakan kesediaan dan kesanggupan untuk berbuat sesuatu yang telah disepakati; c) syarat ; ketentuan yang harus dipenuhi" ${ }^{28}$

Kampanye merupakan "a) gerakan atau tindakan serentak untuk melawan atau mengadakan aksi, dan sebagainya; b) kontes yang dilaksanakan oleh organisasiorganisasi politik atau calon-calon yang bersaing memperebutkan kursi atau jatah atau kedudukan dalam parlemen untuk mendapat dukungan massa pemilih dalam suatu pemungutan suara. Kampanye adalah suatu proses kegiatan komunikasi individu atau kelompok yang dilakukan secara terlembaga dan bertujuan menciptakan suatu efek atau dampak tertentu" ${ }^{\prime 29}$

Secara umum, berbagai peraturan maupun doktrin menegaskan kewajiban untuk memenuhi kepercayaan orang lain sesuai apa yang dijanjikan (promissory estopel). Sehingga jika janji tersebut tidak terpenuhi, ada kewajiban ganti rugi (quasicontract). ${ }^{30}$ Disini pengadilan melindungi kepentingan dan kepercayaan masingmasing pihak. ${ }^{31}$ Grotius menyatakan bahwa "pacta sunt servanda (janji itu mengikat)" sehingga kita harus memenuhi janji kita (promissorum implendorum obligatio). ${ }^{32}$ Anson menyatakan : "A promise more than a mere statement of intention for it imports a willingness on the part of the promiser to be bound to the person to whom it is made." 33 Asas ini tidak hanya berada dalam ranah perdata saja, tetapi bersifat universal. ${ }^{34}$

\footnotetext{
${ }^{28}$ Sudarsono, Kamus Hukum, Rineka Cipta, Jakarta, 1992, h. 194

${ }^{29}$ Pramono Anung Wibowo, Mahalnya Demokrasi Memudarnya Ideologi : Potret Komunikasi Politik Legislator-Konstituen, Kompas, Jakarta, 2013, h. 14

30 Roberto Mangabeira Unger, Gerakan Studi Hukum Kritis, Penerbit Lembaga Studi Dan Advokasi Masyarakat (ELSAM), Jakarta, 1999, h. 80

${ }^{31} \mathrm{Ibid}$, h. 81

${ }^{32}$ Grotius Dalam Miriam Darus Badrulzaman, Dkk, Kompilasi Hukum Perikatan, PT Citra Aditya Bakti, Bandung, 2001, h. 83

${ }^{33}$ Roberto Mangabeira Unger, Op. Cit, h. 78

${ }^{34}$ Miriam Darus Badrulzaman, Dkk, Op.Cit.,h. 83
} 
Janji kampanye dapat disebut juga dengan janji pemilu, karena secara faktual, janji-janji tersebut disampaikan dalam masa kampanye untuk memenangkan pemilu35. Di satu sisi, "janji pemilu" atau "janji kampanye" adalah janji politis atau pejabat pada publik dalam usaha memenangkan pemilu. Contohnya, janji untuk memotong pajak atau untuk memperkenalkan program sosial baru yang menarik pemilih. ${ }^{36}$ Di sisi lain, janji pemilu, meningkatkan keragu-raguan (skeptisme) terhadap sifat dasar politisi yang selalu mengingkarinya setelah mereka menjabat.

Ironisnya, janji kampanye hanya dimaknai dari segi politis dan moralitas saja, sehingga sanksi yang diberikan atas pengingkarannya hanya sebatas sanksi politis dan moral, yaitu kehilangan suara karena rakyat tidak akan memilihnya lagi. ${ }^{37}$ Telah banyak tulisan yang menyangsikan pertanggungjawaban janji kampanye, bahkan sebaliknya, membenarkan jika pertanggungjawaban secara hukum atas janji kampanye adalah sulit, bahkan mustahil dilakukan.

Bintan Saragih dalam Kuliah Sejarah Hukum pada Magister Hukum Trisakti, menyatakan bahwa Janji Cinta dan Janji Politik tidak dapat digugat secara perdata. ${ }^{38}$ Janji politik sangat abstrak dari segi isi dan tidak memenuhi asas-asas dalam perjanjian. Janji kampanye bukan perjanjian yang sah secara hukum, sehingga tidak dapat dimintakan pertanggungjawaban atau pemenuhannya secara hukum. ${ }^{39}$

Sedangkan janji cinta sering menjadi awal pemerkosaan atas nama cinta. Perkosaan saat kencan (date raped) terjadi karena tidak seimbangnya kedudukan pelaku dan korban. Korban harus membuktikan cinta dengan cara bersedia melakukan hubungan seksual dengan pelaku. Sehingga walaupun dalam persidangan dinyatakan bahwa hubungan seksual itu dilakukan secara "suka sama

\footnotetext{
${ }^{35}$ An election promise is a promise made to the public by a politician who is trying to win an election. They have long been a central element of elections and remain so today. Election promises are also notable for often being broken once a politician is in office. Elections promises are part of an election platform, but platforms also contain vague ideals and generalities as well as specific promises. They are an essential element in getting people to vote for a candidate.

Baca : Wikipedia, Election Promise (Online), Http://En.Wikipedia.Org/Wiki/Election_Promise (Diakses 30 April 2014)

${ }^{36}$ Elections promises are a large part of an election platform, which includes several ideas with differing specificity. These ideas of a political platform include general policies, but politicians make sure to also include actual promises that they intend to keep once elected. They are an essential element in getting people to vote for a candidate. For example, a promise such as to cut taxes or to introduce new social programs may appeal to voters.

${ }^{77}$ Kacung Marijan, 10 Oktober 1996, Kampanye, Janji-Janji Dan Pertanggungjawaban (Online), http://www.jawapos.co.id/indones/jawapos/news/today/analysis/a2101096.htm (Diakses 25 April 2014).

38 Albert Aries, 26 Agustus 2009, Janji Politik Dan Janji Cinta (Online), Tanggapan Terhadap Berita Hukumonline Janji Politik Pejabat Tak Bisa Digugat Secara Perdata, 25 Agustus 2009, http://www.hukumonline.com/berita/baca/hol22951/janji-politik-pejabat-tak-bisa-digugatsecara-perdata (Diakses 25 April 2014).

39 Anonim, 25 April 2014, Janji Caleg, Bisakah Ditagih Secara Hukum ? (Online) http://www.gresnews.com/berita/tips/0294-janji-caleg-bisakah-ditagih-secara-hukum/ (Diakses 17 Mei 2014)
} 
suka" atau "mau sama mau", namun pada kenyataannya, secara psikologis korban bersedia melakukan perbuatan tersebut karena berada di bawah intimidasi pelaku. 40

Semakin banyak pihak yang menyangsikan pertanggungjawaban hukum akan janji kampanye dan kontrak politik, semakin tertantang penulis untuk membuktikan sebaliknya. Jika janji cinta bermuara pada pemerkosaan atas nama cinta ${ }^{41}$ (date raped), maka secara mutatis mutandis pengingkaran kontrak politik dan janji kampanye juga berarti pemerkosaan terhadap kedaulatan rakyat sekaligus pengkhianatan terhadap demokrasi. Oleh karena itu kontrak politik dan janji kampanye seharusnya secara hukum dapat ditagih. ${ }^{42}$

Pengingkaran janji kampanye sarat problematik filsafati, normatif dan sosiologis. Secara filsafati, semua janji harus ditepati. Janji adalah hutang. Seluruh agama dan kepercayaan pun sepaham bahwa sebuah janji haruslah ditepati. Bahkan pada bulan Juni 2015, MUI mengadakan forum ijtima' di Tegal untuk menyikapi janji kampanye para ulil amri. Forum ini berujung pada fatwa MUI tentang janji kampanye. 43

Hakekatnya, barangsiapa berjanji, wajib menepati. Majelis Ulama Indonesia (MUI) pun menyelenggarakan forum ijtima' ulama se-Indonesia di Tegal pada Juni 2015, yang membahas tema sentral kepemimpinan : Bagaimana kalau ulil amri tidak menepati janji." 44 Keputusan Komisi A Masalah Strategis Kebangsaan (Masail Asasiyah Wathaniyah) Ijtima' Ulama Komisi Fatwa Se-Indonesia V Tahun 2015 tentang Kedudukan Pemimpin yang Tidak Menepati Janjinya :45

a. "Jabatan adalah amanah yang harus dipertanggungjawabkan pada Allah SWT. Meminta atau merebut jabatan adalah hal tercela, terlebih jika tidak mempunyai kapabilitas. Bagi yang memiliki kompetensi, boleh mengusulkan diri dan berjuang untuk hal tersebut.

40 Penulis Sangat Mengapresiasi Putusan Pengadilan Negeri Medan No. 571/KS/1980/PN.Mdn Yang Menjatuhkan Hukuman Pada Sang "Perayu Gombal", Dan Putusan Tersebut Dikuatkan Oleh Putusan Pengadilan Tinggi No. 144/Pid/1983/PT.Mdn. Namun Putusan Tersebut Dianggap Kontroversial Karena Mempersamakan Kehormatan Wanita Dengan 'Barang', Ironisnya Kemudian Pelaku Diputus Bebas Oleh Mahkamah Agung Melalui Putusan No. 1480 K/Pid/1985. Baca : Bismar Siregar, Hukum Hakim Dan Keadilan Tuhan: Kumpulan Catatan Hukum Dan Peradilan Di Indonesia, Gema Insani Press, Jakarta, 1995, h. 65-67.

${ }^{41}$ Iip Wijayanto, Pemerkosaan Atas Nama Cinta: Potret Muram Interaksi Sosial Kaum Muda, Penerbit Tinta, 2003.

${ }^{42}$ Herulono Murtopo, 17 Februari 2014, Beranikah Legislatif Membuat UU Pidana Untuk Caleg Yang Ingkar Janji? (Online), http://politik.kompasiana.com/2014/02/17/beranikah-legislatifmembuat-uu-pidana-untuk-caleg-yang-ingkar-janji-633765.html (Diakses 17 Mei 2014)

${ }^{43} \mathrm{http}$ ://nasional.tempo.co/read/news/2015/06/12/078674378/Fatwa-MUI-Berdosalah-Pemimpi n-yang-Ingkar-Janji-Kampanye (15 Juni 2015)

${ }^{44}$ Majelis Ulama Indonesia, Ijtima' Ulama Bahas Janji-janji Saat Kampanye (online), 30 April 2015,

http://mui.or.id/mui/homepage/berita/berita-singkat/ijtima-ulama-bahas-janji-janji-saat-kamp anye.html (diakses 11 Juni 2015).

45 Ijtima Ulama Komisi Fatwa se-Indonesia V diselenggarakan di Pondok Pesantren atTauhidiyah, Cikura, Tegal, Jawa Tengah pada tanggal 19-22 Sya'ban 1436 H/ 7-10 Juni 2015 M. Baca : http://mui.or.id_wp-content_uploads_2015_06_MU-Hasil-Ijtima-Ulama-V-tahun-2015 
b. Setiap calon pemimpin publik (eksekutif, legislatif, yudikatif) harus memiliki kompetensi (ahliyyah) dan kemampuan untuk menjalankan amanah tersebut.

c. Calon pemimpin publik tidak boleh mengumbar janji untuk melakukan perbuatan di luar kewenangannya.

d. Calon pemimpin yang berjanji untuk melaksanakan kebijakan dan kemaslahatan yang tidak dilarang oleh syariah, maka ia wajib menunaikannya. Jika diingkari, hukumnya haram.

e. Calon pemimpin publik dilarang menjanjikan sesuatu yang menyalahi agama. Jika menjanjikannya, maka haram dipilih. Jika ternyata terpilih, maka janji dilarang ditunaikan.

f. Calon pemimpin publik yang menjanjikan memberikan sesuatu sebagai imbalan untuk memilihnya, tergolong risywah (suap) hukumnya haram.

g. Pemimpin publik yang melegalkan sesuatu yang dilarang agama, maupun melarang sesuatu yang diperintahkan agama, maka tidak boleh ditaati.

h. Pemimpin publik yang melalaikan tugas, melanggar sumpah, harus dimintai pertanggungjawaban dan diproses sesuai peraturan perundangan yang berlaku.

i. Pemimpin publik yang tidak melaksanakan janji kampanyenya adalah berdosa, dan tidak boleh dipilih kembali.

j. MUI memberi taushiyah pada pemimpin yang ingkar janji dan sumpahnya".

\subsection{Dasar Pertimbangan Hukum Putusan Tentang Gugatan Citizen Lawsuit Terhadap Pengingkaran Janji Kampanye Sebagai Perbuatan Wanprestasi Oleh Pemerintah}

Pada Perkara No. 17/PDT.G/2009/PN.JKT.PST, LPI menggugat SBY-JK yang melakukan wanprestasi karena tak mewujudkan janji kampanye pada Pilpres 2004. ${ }^{46}$ LPI meminta hakim untuk memutus bahwa Presiden SBY dan Wapres JK telah menyalahi janji-janji kampanye pilpres 2004, serta agar SBY-JK meminta maaf secara resmi kepada rakyat dalam pidato kenegaraan, karena tidak dapat memenuhi janji kampanyenya. ${ }^{47}$

Beberapa janji kampanye pada Juni 2004 yang gagal direalisasikan hingga tahun 2009, antara lain : Pertumbuhan ekonomi 7,6 \%, Penurunan angka kemiskinan 17,14 $\%$ menjadi 8,7 \%. Komitmen itu kembali ditegaskan pada pidato kenegaraan SBY-JK sebagai presiden dan wakil presiden. ${ }^{48}$ Realisasi janji tersebut bertentangan dengan fakta dari Badan Pusat Statistik (BPS) angka kemiskinan selalu di atas $15 \%$, yaitu 15,9 \% (tahun 2005); 17,6 \% (tahun 2006); 16,4 \%(tahun 2007); dan 15,4 \% (tahun 2008) atau mencapai 34,9 juta jiwa penduduk Indonesia masih hidup di bawah garis

\footnotetext{
${ }^{46}$ Hukumonline, 25 Agustus 2009, Janji Politik Pejabat Tak Bisa Digugat Secara Perdata (Online), http://www.hukumonline.com/berita/baca/hol22951/janji-politik-pejabat-tak-bisa-digugatsecara-perdata (Diakses 25 April 2014)

47 Ibid

48 Ibid
} 
kemiskinan. Sedangkan tingkat pengangguran dari 10,1 \% menjadi 5,1 \% juga tidak terealisasi. ${ }^{49}$

Penggugat menyatakan, pertumbuhan ekonomi sebesar 5,5 \% sehingga SBY-JK belum memenuhi janji kampanyenya dan dikategorikan wanprestasi. Menurut kuasa hukum SBY-JK, tingkat kemiskinan sebesar 15,54 \% (tahun 2008), turun dari 17,7 \% (tahun 2005), dan pertumbuhan ekonomi sebesar 6,4\%. Dimana Rancangan Kinerja Pemerintah 2010-2014 sudah menurunkan target pertumbuhan ekonomi menjadi 5,5 $\%$ (turun dari target sebelumnya). ${ }^{50}$

Namun dalam putusan pada 24 Agustus 2009, Ketua Majelis Hakim PN Jakarta Pusat, Makmun Masduki, menyatakan kegagalan SBY-JK memenuhi janji kampanye bukan wanprestasi. Ketidakberhasilan janji politik itu bukan karena kesengajaan sehingga tidak bisa menjadi sengketa hukum. Janji politik bukan janji dalam konteks hukum perdata. Pernyataan SBY-JK merupakan janji politik yang pelaksanaannya lebih dipengaruhi faktor faktor politik. Kondisi ekonomi global juga menjadi faktor signifikan dalam keberhasilan janji kampanye. Meskipun janji politik belum dituntaskan, kemampuan SBY-JK dalam menurunkan angka kemiskinan dan menaikan pertumbuhan ekonomi patut diacungi jempol. ${ }^{51}$

Menurut peneliti, ratio decidendi majelis hakim tersebut sudah tepat. Janji kampanye tidak memenuhi syarat sahnya perjanjian dalam Pasal 1320 Kitab Undang-undang Hukum Perdata (KUHPerdata). Pasal 1320 KUHPerdata menyatakan: "Untuk sahnya perjanjian-perjanjian diperlukan empat syarat: 1) Sepakat mereka yang mengikatkan dirinya; 2) Kecakapan untuk membuat suatu perikatan, 3) Suatu hal tertentu; dan 4) Suatu sebab yang halal." Kesepakatan dan kecakapan adalah syarat subyektif dalam perjanjian. Jika tidak terpenuhi, maka perjanjian batal demi hukum. Sedangkan hal tertentu dan causa halal merupakan syarat obyektif, jika tidak terpenuhi maka perjanjian tersebut dapat dibatalkan. ${ }^{52}$

Penawaran janji kampanye oleh kandidat Presiden dan Wakil Presiden, sehingga keputusan pemilih untuk memilih pasangan calon tersebut tidak memenuhi syarat subyektif dalam perjanjian. Kesepakatan sebagai syarat subyektif tidak terpenuhi karena Pemilu menggunakan asas Langsung, Umum, Bebas, Rahasia, Jujur, dan Adil (LUBER JURDIL). ${ }^{53}$ Kesepakatan para pihak mengikatkan diri dalam janji kampanye tidak dapat dibuktikan. Keputusan untuk memilih Pasangan Calon disalurkan melalui kotak

\footnotetext{
49 Ruslan Burhani, Loc.Cit.

${ }^{50}$ HukumOnline, Loc.Cit.

51 Ibid.

52 Subekti dan Tjitrosudibio. Kitab Undang-Undang Hukum Perdata. Jakarta: Pradnya Paramita, 1992, h. 283.

53 Pasal 2 UU No. 42 Tahun 2008 tentang Pemilihan Presiden dan Wakil Presiden : "Pemilu Presiden dan Wakil Presiden dilaksanakan secara efektif dan efisien berdasarkan asas langsung, umum, bebas, rahasia, jujur, dan adil." Sedangkan Pasal 2 UU No. 7 Tahun 2017 tentang Pemilihan Umum : "Pemilu dilaksanakan berdasarkan asas langsung, umum, bebas, rahasia, jujur, dan adil."
} 
pemungutan suara ${ }^{54}$. Tidak dapat dibuktikan bahwa seseorang telah memilih Pasangan Calon tertentu karena surat suara bersifat anonim.55 Pemilih dilarang memberikan tulisan dan/atau catatan lain pada surat suara. Surat suara yang terdapat tulisan dan/atau catatan lain dinyatakan tidak sah. ${ }^{56}$

Selain itu terdapat konsekuensi yuridis yang berbeda diantara janji kampanye dan janji keperdataan. Janji keperdataan mengikat sejak kesepakatan berdasarkan asas Pacta Sunt Servanda (perjanjian mengikat para pihak yang bersepakat bagaikan undang-undang) ${ }^{57}$ dan pengingkaran terhadap janji keperdataan merupakan wanprestasi5s. Sedangkan janji politik mengikat setelah Pasangan Calon tersebut memenangkan pemilu. Janji kampanye ditawarkan saat menjadi kandidat, namun dipenuhi setelah berstatus Presiden dan Wakil Presiden. Pengingkaran terhadap janji politik tidak ada istilah hukumnya.

Hasil Pilpres dituangkan dalam Keputusan Komisi Pemilihan Umum (KPU) ${ }^{59}$ yang berlaku secara individual dan konkret, serta memberikan status hukum Presiden dan Wakil Presiden terpilih untuk kemudian dilantik oleh Majelis Permusyawaratan Rakyat (MPR).

Bagi kandidat yang kalah Pilpres tidak menerima Keputusan KPU tersebut, dapat mengajukan gugatan sengketa hasil Pilpres pada Mahkamah Konstitusi (MK). Janji politik kandidat yang kalah Pilpres tidak relevan untuk ditagih karena tidak mengikat siapa pun. Janji kampanye kandidat yang kalah dalam Pilpres tidak mungkin direalisasikan karena tidak memiliki kewenangan menjalankan pemerintahan.

Oleh karena pengingkaran janji kampanye tidak memenuhi klasifikasi wanprestasi, maka menurut peneliti diperlukan kajian hukum lain untuk meminta pertanggungjawaban janji kampanye. Pengingkaran janji kampanye

\footnotetext{
54 Jonathan Wolff, Pengantar Filsafat Politik, (Bandung: Nusa Media, 2013), h. 65

55 Ronald B. Standler, 29 April 2012, Promises By Political Candidates Not Legally Enforceable In The USA (online), www.rbs2.com/elecprom.pdf (diakses 27 Juli 2015 Pk. 17.12 WIB).

${ }^{56}$ Pasal 125 ayat (1) dan (2) UU Pilpres jo Pasal 365 ayat (1) dan (2) UU Pemilu

57 Pasal 1338 ayat (1) KUHPerdata : "Semua perjanjian yang dibuat secara sah berlaku sebagai undangundang bagi mereka yang membuatnya..." Baca : Subekti dan Tjitrosudibio, Op.Cit, h. 285.

58 Wanprestasi berasal dari bahasa Belanda, wanprestatie, artinya kelalaian, kealpaan, prestasi yang buruk atau tidak melaksanakan prestasi. Baca : Sudarsono, op. cit., hlm. 578-579. Ketentuan mengenai wanprestasi terdapat pada Pasal 1238 KUHPerdata : "Si berutang adalah lalai, apabila ia dengan surat perintah atau dengan sebuah akta sejenis itu telah dinyatakan lalai, atau demi perikatannya sendiri, ialah jika ini menetapkan, bahwa si berutang akan harus dianggap lalai dengan lewatnya waktu yang ditentukan." Baca pula : Subekti dan Tjitrosudibio, Op.Cit, h. 269.

59 Keputusan KPU No. 535/Kpts/KPU/Tahun 2014 tentang Penetapan Rekapitulasi Hasil Penghitungan Perolehan Suara dan Hasil Pemilihan Umum Presiden dan Wakil Presiden Tahun 2014 (22 Juli 2014) dan Keputusan KPU No. 536/Kpts/KPU/Tahun 2014 tentang Penetapan Pasangan Calon Presiden dan Wakil Presiden Terpilih dalam Pemilihan Umum Presiden dan Wakil Presiden Tahun 2014 (22 Juli 2014).
} 
tidak cukup hanya diberikan sanksi moral (rusaknya nama baik dan reputasi kandidat) maupun sanksi politis (hukuman elektoral ${ }^{60}$ ). Pengingkaran janji kampanye harus dapat dipertanggungjawabkan secara hukum. Diperlukan mekanisme hukum lain untuk memaksa Presiden terpilih untuk memenuhi janji kampanyenya.

\section{PENUTUP}

Mengenai gugatan citizen lawsuit terhadap pengingkaran janji kampanye sebagai wanprestasi oleh pemerintah, hakim PN Jakarta Pusat telah membuat putusan yang tepat. Janji kampanye tidak memenuhi syarat sahnya perjanjian menurut Pasal 1320 KUHPerdata, sehingga pengingkaran janji kampanye bukan wanprestasi.

Diperlukan kajian hukum lain untuk meminta pertanggungjawaban janji kampanye. Pengingkaran janji kampanye tidak cukup hanya diberikan sanksi moral maupun sanksi politis, namun harus dapat dipertanggungjawabkan secara hukum. Diperlukan mekanisme hukum lain untuk memaksa Presiden terpilih untuk memenuhi janji kampanyenya.

\section{DAFTAR PUSTAKA}

\section{Buku}

Badrulzaman, Mariam Darus. Kompilasi Hukum Perikatan : Dalam Rangka Mempertingati Memasuki Masa Purna Bakti Usia 70 Tahun. Bandung : Citra Aditya Bakti, 2001.

Indrayana, Denny. Negara Antara Ada Dan Tiada : Reformasi Hukum Ketatanegaraan,

Penerbit Buku Kompas, Jakarta, Juni 2008,

Marzuki, Peter Mahmud. Penelitian Hukum. Jakarta: Kencana, 2011.

MD, Moh. Mahfud. Konstitusi Dan Hukum Dalam Kontroversi Isu, Rajawali Pers, Jakarta, 2010

Mulyana, Deddy. Komunikasi Politik, Politik Komunikasi : Membedah Visi Dan Gaya

Komunikasi Praktisi Politik, PT Remaja Rosdakarya, Bandung, 2013

Pamungkas, Sigit. Perihal Pemilu, Laboratorium Jurusan Ilmu Pemerintahan Dan Jurusan Ilmu Pemerintahan Universitas Gadjah Mada, Yogyakarta, 2009, halaman vii Sayuti, Solatun Dulah. Komunikasi Pemasaran Politik, PT Remaja Rosdakarya, Bandung, 2014

\footnotetext{
${ }^{60}$ Hukuman elektoral berupa tidak lagi dipilih oleh rakyat pada pemilu selanjutnya. Di tengah berbagai tingkat kedewasaan berpolitik warga negara, sejarah Indonesia membuktikan setelah reformasi, tidak ada partai politik yang menang 2 (dua) kali berturut-turut. Pemilu tahun 1999 dimenangkan oleh Partai Demokrasi Indonesia Perjuangan (PDIP), Golongan Karya (Golkar) pada 2004, Partai Demokrat pada 2009, dan 2014 oleh PDIP. Lihat : Yunarto Wijaya (analis politik) Direktur Eksekutif Charta Politika, Menanti Sanksi Setya, MetroTV LIVE, 15 Desember 2015, Pk.18.20 WIB
} 
Siregar, Bismar. Hukum Hakim Dan Keadilan Tuhan: Kumpulan Catatan Hukum Dan

Peradilan Di Indonesia, Gema Insani Press, Jakarta, 1995

Subekti dan Tjitrosudibio. Kitab Undang-Undang Hukum Perdata. Jakarta: Pradnya

Paramita, 1992.

Sudarsono, Kamus Hukum, Rineka Cipta, Jakarta, 1992

Susmayanti, Riana. Materi Kuliah Hukum Pemerintahan Daerah, Fakultas Hukum

Universitas Brawijaya, Malang, 2012

Wijayanto, Iip. Pemerkosaan Atas Nama Cinta: Potret Muram Interaksi Sosial Kaum

Muda, Penerbit Tinta, 2003

Wibowo, Pramono Anung. Mahalnya Demokrasi Memudarnya Ideologi : Potret

Komunikasi Politik Legislator-Konstituen, Kompas, Jakarta, 2013

Wolff, Jonathan. Pengantar Filsafat Politik, Bandung: Nusa Media, 2013

Unger, Roberto Mangabeira. Gerakan Studi Hukum Kritis, Penerbit Lembaga Studi Dan Advokasi Masyarakat (ELSAM), Jakarta, 1999

\section{Surat Kabar}

Olla, Paulinus Yan. Rakyat Dan Kepemimpinan, Kompas, 19 Oktober 2013

\section{Naskah Internet}

Anonim, 25 April 2014, Janji Caleg, Bisakah Ditagih Secara Hukum ? (Online) http://www.gresnews.com/berita/tips/0294-janji-caleg-bisakah-ditagih-secarahukum/ (Diakses 17 Mei 2014)

Aries, Albert. 26 Agustus 2009, Janji Politik Dan Janji Cinta (Online), Tanggapan Terhadap Berita Hukumonline Janji Politik Pejabat Tak Bisa Digugat Secara Perdata, 25 Agustus 2009, http://www.hukumonline.com/berita/baca/hol22951/janji-politik-pejabat-takbisa-digugat-secara-perdata (Diakses 25 April 2014)

Burhani, Ruslan. Kamis, 19 Februari 2009, PN Jakpus Tunda Sidang Gugatan LPI Terhadap SBY-JK, http://www.antaranews.com/berita/133289/pn-jakpus-tundasidang-gugatan-lpi-terhadap-sby-jk.

Fahran, Kony. Februari 2014, Pasca Pemilu Caleg Depresi Berat Diprediksi Naik 20 Persen (Online), Jakarta, http:/ / beritakaltara.com/ ?p=2777 (Diakses 17 Mei 2014)

Ferdian, Rully. Janji Muluk Parpol Di Masa Kampanye (Online), http://www.infobanknews.com/2014/03/janji-muluk-parpol-di-masakampanye/nasional. Diakses 25 April 2014.

Hukumonline, 25 Agustus 2009, Janji Politik Pejabat Tak Bisa Digugat Secara Perdata (Online), http://www.hukumonline.com/berita/baca/hol22951/janji-politikpejabat-tak-bisa-digugat-secara-perdata (Diakses 25 April 2014).

http://nasional.tempo.co/read/news/2015/06/12/078674378/Fatwa-MUI-BerdosalahPemimpin-yang-Ingkar-Janji-Kampanye (15 Juni 2015).

http://mui.or.id_wp-content_uploads_2015_06_MU-Hasil-Ijtima-Ulama-V-tahun-2015 LPI Resmi Gugat SBY-JK, http://partaigerindra.or.id/2009/01/23/lpi-resmi-gugatsby-jk.html (8 Juli 15). 
Majelis Ulama Indonesia, Ijtima' Ulama Bahas Janji-janji Saat Kampanye (online), http:/ / mui.or.id/mui/homepage/berita/berita-singkat/ijtima-ulama-bahas-janji-j anji-saat-kampanye.html (diakses 11 Juni 2015)

Marijan, Kacung. 10 Oktober 1996, Kampanye, Janji-Janji Dan Pertanggungjawaban (Online), http://www.jawapos.co.id/indones/jawapos/news/today/analysis/a2101096.ht m (Diakses 25 April 2014)

Murtopo, Herulono. 17 Februari 2014, Beranikah Legislatif Membuat UU Pidana Untuk Caleg Yang Ingkar Janji? (Online), http:/ / politik.kompasiana.com/2014/02/17/ beranikah-legislatif-membuat-uupidana-untuk-caleg-yang-ingkar-janji-633765.html (Diakses 17 Mei 2014)

Standler, Ronald B. 29 April 2012, Promises By Political Candidates Not Legally Enforceable In The USA (online), www.rbs2.com/elecprom.pdf. diakses 27 Juli 2015 Wibowo. Mataharinews.Com, Yogyakarta, 26 Maret 2014, Obral Janji Dalam

Kampanye Indikasi Bipolar (Online), http://www.mataharinews.com/nusantara/jawa-bali/3753-obral-janji-dalamkampanye-indikasi-bipolar.pdf (Diakses 17 Mei 2014)

Wikipedia, Election Promise (Online), Http:/ /En.Wikipedia.Org/Wiki/Election_Promise (Diakses 30 April 2014)

\section{Peraturan Perundang-undangan}

Kitab Undang-undang Hukum Perdata

UU No. 42 Tahun 2008 tentang Pemilihan Presiden dan Wakil Presiden

UU No. 7 Tahun 2017 tentang Pemilihan Umum

\section{Yurisprudensi}

Putusan PENGADILAN NEGERI JAKARTA PUSAT Nomor 17/PDT.G/2009/PN.JKT.PST 